\title{
Racism In Germany And The Global Consequences For Premium Brands
}

https://doi.org/10.21272/sec.3(2).54-62.2019

\section{Dirk Zwerenz}

PhD Student, University Kaposvár Germany, Hungary; German Doka formwork technology GmbH, Germany

\section{Abstract}

This paper summarizes current political discussions and reports on xenophobic demonstrations and racist riots in the Saxon city of Chemnitz and contrasts them with the global context of the brand image of a premium watch manufacturer.

Chemnitz is a city in Saxony (in East Germany) with approx. 250,000 inhabitants. It examines the impact of images in the media and videos the medium-sized company NOMUS. The manufacturer is the company of NOMUS, a medium-sized manufacturer of luxury watches. NOMUS sold its luxury products in international cities all over the world. The production of watches takes place in the small town $>$ Glashütte $<$. Glashütte is approx. $80 \mathrm{~km}$ away from Chemnitz, approx. 7,300 inhabitants live in Glashütte. NOMUS supplies a worldwide dealer network with subsidiaries in the USA, Canada, Cuba, Argentina, the U.A.E., India, China, Japan, Australia and Europe. NOMUS has 250 employees in the glassworks and 50 employees in a design studio in Berlin.

The main purpose of the research is to present the regional effects of racism in a Central German city on the national level of Germany and to evaluate the global economic effects for the location Germany as such and the premium manufacturer of high-priced watches in particular. Subsequently, individual solutions for the local situation in the company and strategies for global marketing are subsumed. To describe the emergence of brand values, scientific literature is used; to systematize the current media coverage, the daily press must be used, in deviation from the scientific claim, since there are significant indications that the daily press has a significant influence on the perspective of the end customers of the premium watch manufacturer in the B2C business. A quantitative collection of customer data is dispensed with, and the expert interview is used as a methodical tool with the owners and managing directors of the watch manufacturer NOMUS ${ }^{1}$. The aim of the research is also to empirically analyses the countermeasures taken in the company NOMUS and to theoretically confirm their transferability to similar constellations. The research can be useful for the targeted control of reconnaissance campaigns and the targeted control of marketing activities in the international target countries.

The article should explicitly not be a political classification of the current demonstrations. The article should not occupy any pages. The article only examines the impact of regional media events on NOMUS' global business.

Keywords: brand values, racist riots in Saxony, NOMUS-Glashütte, watch manufacturers in the premium segment, employee training against racism, world market for high-quality watches, regional economy.

JEL Classification: A20, D40, M14, M51.

Cite as: Zwerenz, D. (2019). Racism In Germany And The Global Consequences For Premium Brands. SocioEconomic Challenges, 3(2), 54-62. https://doi.org/10.21272/sec.3(2).54-62.2019.

(C) The Author, 2019. This article is published with open access at Sumy State University.

\section{Introduction}

As a regional manufacturer of luxury and premium products with a global market, "small" manufacturers such as NOMUS rely above all on their brand image. Vera König describes the word mark as follows: "a sign of trust and that the customer is willing to pay a higher price" (König, 2017b). The ultimate keyword in this explanation of the term is the word $>$ trust $<$. Potential customers need confidence in the brand, the product,

${ }^{1}$ NOMUS Glashütte/SA Roland Schwertner KG, https://nomos-glashuette.com 
the way I manufacture, the way in which working conditions in the company. The customers lack confidence, they turn away from the brand and buy another product with a better image that they consider to be comparable. If you combine production on the basis of high quality and generally accepted quality with modern and contemporary design, you can add the word $>$ Premium $<$. The term emerges $>$ Premium $<$. This is how Vera König describes the term $>$ premium brand $<$ : "In contrast to a conventional brand, customers expect high quality at a high price from a premium brand" (König, 2017b). Customers with a premium brand combine the desire for exclusivity, the desire for affiliation to authenticate the request with the brand's image in public of a particular social group. One can also speak of status symbols. In addition to the outstanding technical properties and the outstanding design, the way in which the products are manufactured and their origin are of particular importance to the customers of premium brands. The origin of the products is at the same time associated as a symbol for the quality of the brand. Made in Germany has been available for such a quality promise for many years. Made in Germany does not only mean Germany as a country, but for a global clientele it means this as a mirror of their luxury article.

The racist demonstrations with riots against asylum seekers took place in a single city, Chemnitz. The regional and national media reported very extensively on these events. Chemnitz is approx. $80 \mathrm{~km}$ away from the production site of NOMUS Glashütte. The two cities have nothing at all to do with each other because of their great distance by regional standards. Unfortunately, this perception of the great regional distance from each other is not the same for all people. In an interview with the weekly newspaper > Zeit <, Ms Borowski, the managing director of NOMUS, describes the context for outsiders: "For those who live here, Chemnitz is Chemnitz, Chemnitz is Saxony", "for someone from Baden-Württemberg, Chemnitz is Saxony" and further "and for Americans or Italians Saxony is Germany; not only Saxony > made in Germanyy < is in danger" (Baurmann, 2018). The mental, emotional and ethical distortions that arise from racism and what effects these can have on the relationship between companies and customers were described by Prof. Michael Reich (Reich, 1981).

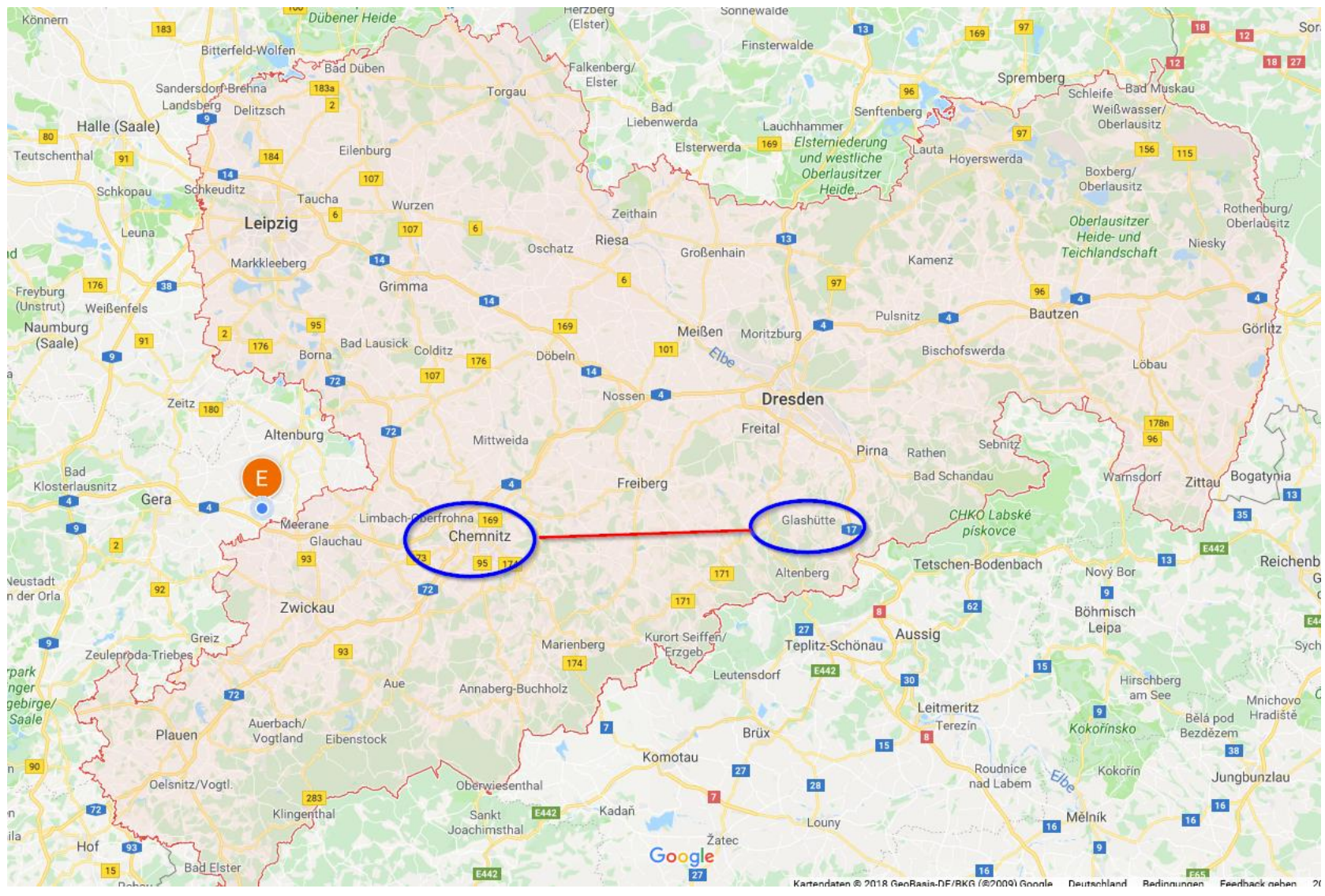

Figure 1. Graphic Glashütte vs Chemnitz

The map shows Germany, drawn in red and blue in the Free State of Saxony, the cities of Chemnitz and Glashütte orbiting $80 \mathrm{~km}$ apart. 


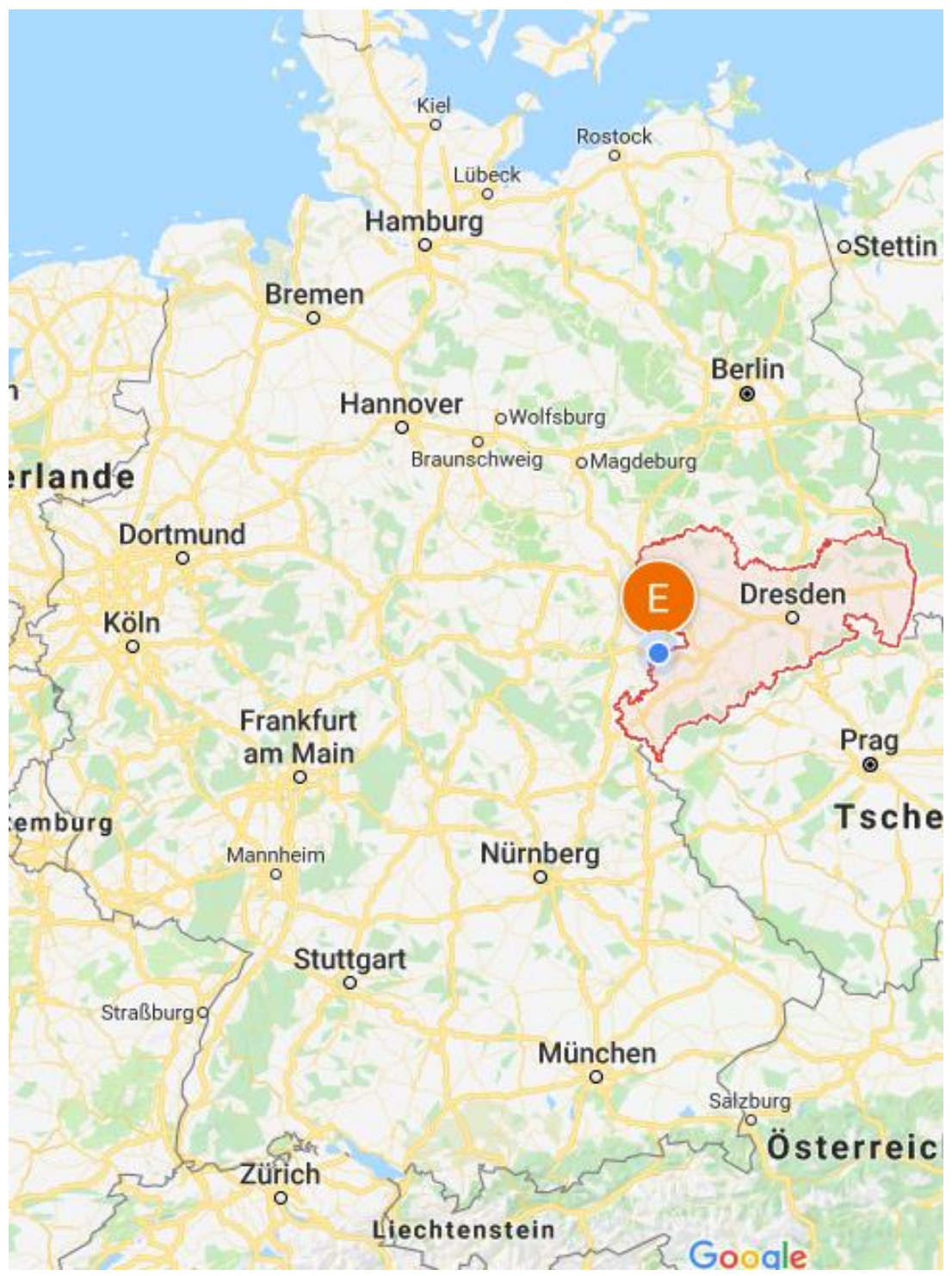

Figure 2. Graphic Location Saxony in Germany

\section{Literature survey}

For this paper we have three categories A), B), C) which have been examined by the scientific literature. The following literature can be identified as relevant:

Category A) Brand, Luxury, Premium: many research projects dealing with the definition of the terms brand, luxury, premium and premium brand. Some books explain the right marketing measures for building your own brand and show the right sales strategies.

King, V. (2017). Communication. In the basics of luxury and premium brand management (pp. 79-95). https://doi.org/10.1007/978-3-658-10746-8 (King, 2017a). Verena König describes how, with the help of communication, brand values and the promise of brands can be expressed and transported to the consumer in the luxury segment of private trade. The signals that premium articles send (or should send) to the customer and the communication requirements for these different signals are described in two different principles, the STAR principle and the DIVA principle. The STAR principle focuses on the quality features of the brand. The price management depends on the presumed willingness to pay of the customers of this brand and the service of the brand is over the entire life cycle of the product (incl. after the sale) on premium level to satisfy the high customer demands. These added values are, of course, promoted loudly by STAR brands. The DIVA principle, on the other hand, strives for a view based on extraordinaryness, unusual design and avant-garde. The connection between the qualitative added value of the exclusive products and the high price is relegated to the background and manifests itself rather in a lower availability (long order periods for the products) and 
a high seduction of the external appearance. DIVA brands live from names and therefore need much less intensive marketing.

Thieme, M. W. P. D. (2017). Further development of the luxury brand in digital times. Brand, e-journal, (April), 72-78. https://doi.org/10.1007/978-3-658-11090-1 (Thieme, 2017). Prof. Dr. Thieme holds the Chair of Marketing at the Faculty of Business Administration at the Munich University of Applied Sciences. In the listed article, which appeared on the occasion of his lecture at the conference "Luxury - Quo vadis" in 2017, he describes which current developments in the field of brand management could be identified. In doing so, he makes basic statements which can be traced back to young customers (he calls these customers "millennials") and their networking in the modern media and thus directly describe the problem and the reason for action of NOMUS. The first statement is "The Millennials have high demands on brands and are extremely well informed" and the second is "The luxury brand must be equally present on all channels today, must ensure a consistent and exciting experience with the brand and product at all times and everywhere". The research results of Prof. Thieme make it clear that luxury brands have to conduct particularly good lobbying work in the modern media in the fight for new (young) buyers and that they also have to be interested in the opinion of their buyers in the phase after the purchase.

King, V. (2017). Distribution and sales promotion. In the basics of luxury and premium brand management (pp. 67-78). https://doi.org/10.1007/978-3-658-10746-8 (King, 2017b). In a further publication, König describes how important it is for STAR brands "especially in the fashion sector" to receive "credible brand recommendations" from their users for further new customers as social media becomes more widespread. König describes the effect of bloggers and influencers as "multipliers and trend barometers". This makes it clear why a negative image due to unjustified racist news, especially for companies like NOMUS, can be a threat to a company's existence.

Märk, S., \& Situm, M. (2018). A business opportunity - an entrepreneur - a country and then the world. In family businesses and their stakeholders (pp. 207-235). Springer Trade Media Wiesbaden. (Märk \& Situm, 2018). Märk and Situm describe in the listed chapter as part of the 2018 book > Family Businesses and their Stakeholders $<$ which decisive role it has for family businesses in international business, with which region the origin of the company is associated in international business. They work out that the identity and message of the brand name in question are directly related to the location of the company and the place of production. Märk and Situm give recommendations for action what has to be considered in the "internationalisation process" of the craft. The transferability of the research results to NOMUS as a regional family business with an international clientele is undoubtedly given.

Janning backfish, N. (2018). Deterministic environmental factors for competence and qualification requirements of logistics companies. In competence and qualification requirements in logistics (pp. 139-273). Springer Nature. (Janning-Backfisch, 2018). The authors of this study analyze a change in social values that can be traced back to legal and political factors and describe the nature of national policy as a decisive condition for the challenges of internationalization. The consequences of regional politics (at least the international opinion about the national politics) and the social and international change of values are felt by NOMUS in the inquiries about the racist riots in the region around its production sites in its global sales markets.

$>\quad$ Category B) national and international publications on NOMUS products, the NOMUS brand and products in the same segment.

Develi, M. (2017). International Marketing. Marketing management. https://doi.org/10.1007/978-3-65813656-7 20 (Develi, 2017). In his work Develi deals specifically with the international marketing of various manufacturers of luxury watches for the Dubai market. Using the example of Dubai, it will be analysed which special requirements are placed on the international watch industry in a Muslim country. What is relevant for NOMUS is that "in the age of globalization it has become unavoidable for companies to offer their products internationally in order to remain competitive" (Berndt, Altobelli, \& Sander, 2018).

Balbontìn, R. (2017). conceptos. TR Tiempo de Relojes, (November), 57th (Balbontìn, 2017). The Mexican Journal reports on the exceptionally clear design of NOMUS and thus demonstrates the very high importance of international sales markets for the economic success of a local craft company.

Shteyngart, G. (2017). Time-out. Black Enterprise, 37(March), 74. Retrieved from http://search.ebscohost.com/login.aspx?direct=true $\& d b=b t h \& A N=22902844 \&$ site=ehost-live $\quad$ (Shteyngart, 2017$). \quad$ The 
American Journal reports on NOMUS as a modern and innovative premium brand. This is further proof of the necessary positive impact on the international economy.

Ewing, J. (2017). "Our clocks don't cheep." The New York Times, p. 2. (Ewing, 2017). In its November 2017 issue, the renowned New York Times newspaper reports that NOMUS products follow a clear and functional design and combines this with an interview with the managing directors of NOMUS, Judith Borowski and Uwe Ahrendt. On this remarkable international stage such as The New York Times, NOMUS' internal corporate values are brought into harmony with the external functionalities of its products. A negative image of NOMUS would destroy this intangible value.

Bassi, A. (2018). Design in Movimento. Revolution Italy, (June), 210-211. (Bassi, 2018). In the Italian Journal in 2018, the clear design of NOMUS is acknowledged and the very high quality of the production of the watches is described. The international reputation of the NOMUS brand continues to increase with this article in the trade press.

Buck, C. L. (2018). Life in the fast lane. eLife, 7(June), 40. https://doi.org/10.7554/eLife.35029 (Buck, 2018). This article in the American Journal $>$ Watchtime $<$ also describes the clear and expressive design of NOMUS watches. Even the slightest indication of a manufacturing shortcoming would frighten NOMUS' discerning clientele.

Hallmann, G. (2017). From Glashütte via Berlin to New York from the Erzgebirge to the whole world "More Marathon than Muckibude" (Hallmann, 2017). Hallmann reports 2107 in his article about the challenges of a small local manufacturer like NOMUS it is to be able to exist in the international premium market beside such names like ROLEX. In addition to the will and the clear objectives of the management, he also emphasizes the corporate values as an essential success factor.

Franke, J.-D. (2015). So far best times for watch manufacturer Nomos India. Free Press, (December), 1st (Franke, 2015). In 2015, Franke reports on the growth NOMUS has achieved to date. It is made clear that further growth (which is necessary for further innovations) can only be achieved through more intensive development of international markets. The dependence of an outstanding brand image as a prerequisite for tapping international customers becomes clear.

Watch industry, D., \& Bei, M. (2017). Nomos Glashütte presents a dream balance. Dresden Latest News. (Editorial Network, 2017). The article reports in 2017 that despite a difficult environment in the international watch industry, NOMUS was able to show a fantastic balance for NOMUS. The statement of the management is quoted after NOMUS always wants to surprise its international customers with innovations. NOMUS' dependence on the spread of positive customer opinions in all media is held responsible for this growth.

Baurmann, J.G. (2018). Counterclockwise. The time, 1(September), 25th (Baurmann, 2018). Germany's leading weekly newspaper Die ZEIT also reports in its issue number 30 in September 2018 that, contrary to the general trend in the watch industry, NOMUS can boast a positive business development and attributes this not least to the positive international image of NOMUS.

Will, R. (2018). Clear message. The mirror, 2(September), 70-71. (Wille, 2018). The problems with a poor regional image of NOMUS' home region are described in this publication. The direct dependence of the international reputation and the economic success of the NOMUS brand is reported. The article also describes measures taken by the company to distance itself from the deteriorating image of the Chemnitz region. The entrepreneur describes the situation as critical for the international markets of the traditional manufacturer.

$>\quad$ Category C) Studies on the development of East German cities and the perception of East Germans in Europe

Bradley, J., Morgenroth, E., \& Untiedt, G. (2011). Analysis of the macroeconomic impact of the CSF on the East German economy Germany : Research project within the framework of an EU Treaty supports the development of a model for assessing the macroeconomic impact of the Structural Funds in East Germany. Wirtschaftsblätter, 2-3. downloaded from https://econpapers.repec.org/RePEc:ces:ifodrs:30 (Bradley, Morgenroth, \& Untiedt, 2011). In a summary of their research, the authors describe in 2011 how the structurally weak regions of eastern Germany can be brought closer to the average standard of living in the European Union. They compile tools from which they assume that this can be realized. One of these tools is the investment of private capital in regional brands to strengthen the regional economy and the renunciation of a 
continuing dependence on subsidies. Strong regions bring economic prosperity to the population living there. Following this example, NOMUS invests a lot in its plant and the prosperity of its regional employees.

Brandmeyer, M. (2016). Success pattern of the Dresden brand. Retrieved from https://mediaserver.dresden.de/categories.php?cat_id=631 (Brandmeyer, 2016). The study published in 2016 deals with the development of the DRESDEN brand in 2015 compared to 2010. It becomes clear that Dresden has a very good and high international reputation as a city and that the regional economy can profit from it in international markets. However, the study also makes it clear that negative local influences and negative television reports from the city of Dresden itself can very quickly be projected onto companies in the region. Particularly among students, researchers and scientists, the image of the city of Dresden deteriorated during the period under review. This group can be regarded as a latent customer group for NOMUS and could therefore be an indicator of an imminent deterioration in the international image of NOMUS.

Smart guy, J. (2011). Growth and employment in Dresden - Why is Dresden growing more slowly than the rest of Saxony? Publications by researchers from the ifo Institute - Leibniz Institute for Economic Research at the University of Munich ifo Dresden reports, ifo Institute - Leibniz Institute for Economic Research at the University of Munich, 10th download from http://hdl.handle.net/10419/169968 (Kluge, 2011). In his paper for 2011, Kluge deals with the question of why the economic region around Dresden is growing more slowly than the rest of Saxony. He comes to the conclusion that the Dresden region lacks business enterprises that have a deep value chain. The economy of the Dresden region currently benefits more from the service sector, which is very volatile and of course only regionally limited. This makes companies such as NOMUS with an international sales area all the more important for the Dresden region and the inhabitants of the city and the surrounding area.

Glashütte: Key figures and ranking in the SME ranking. (2018). The German economy. ('Glashütte: Key figures and ranking in the SME ranking', 2018). The ranking of medium-sized companies describes NOMUS Glashütte as number 4,661 of the 10,000 most important medium-sized companies in Germany and thus gives an insight into the significance and the economic situation of the company.

\section{Methodology and research methods}

The political, social and economic perception of Germany in the world has a significant influence on the international success of German premium brands.

Due to the limited scope of this research task, the proof of this hypothesis is given using the example of the regional manufacturer of premium watches NOMUS, the influential conditions current demonstrations in Chemnitz are shown as a significant feature on the international business of NOMUS. A survey commissioned by Dresden Marketing GmbH in 2015 on the success patterns of the Dresden brand (state capital Saxony) and conducted by Brandmeyer, the brand consultancy, serves as a statistical reference (quantitative research component) for the image of the people of the world in the Saxony region (Brandmeyer, 2016). The effects on the international brand image of NOMUS, depending on the negative news in the daily press, is described in an interview with the weekly newspaper $>$ Die Zeit $<$ by Mrs Borowski, the managing director of NOMUS, as an expert survey. This expert survey can be regarded as a qualitative component of research.

\section{Outcomes}

Chemnitz, September 1, 2018: On the outskirts of the Chemnitz City Festival (August 24 to 26), a man is fatally injured with stab wounds. There are rumours going around that the perpetrator has a migration background. In the next episode, a demonstration against the current situation in the city of Chemnitz will take place on 01 September 2018. The demonstration is infiltrated by right-wing groups, with riots with counter protests, police and journalists. Images of violence go through German media, images of violence all over the world. The > City of Modernity <, as Chemnitz himself spoke of a bad reputation in Saxony, a bad reputation in Germany and a bad reputation in the world.

Glashütte since 1990: Since 1845 watches have been produced in the small town of Glashütte in the eastern Erzgebirge mountains. From 1951 to 1990 the production of many small companies was brought together in 
the $>$ Glashütter Uhrenbetriebe VEB (GUB) $<$. After the reunification of Germany, the GUB was reprivatised by the Treuhandanstalt in $1990 .^{1}$

The small town is home to many world-renowned manufacturers of high-priced premium watches. Some of the best known brands are $>$ Lange \& Söhne $<,>$ Original Glashütte $<,>$ Bruno Söhnle $<,>$ Mühle Glashütte $<$ and $>$ NOMUS < . All manufacturers produce handmade watches and how are they in Germany, Europe and on the world market against the market leader Casio and other well-known brands $>$ Breitling $<,>$ Rolex $<$, $>$ Cartier $<$, > Swatch $<$, > Junghans $<$ and other well-known brands claim. Successful manufacturers in the premium segment through uniqueness, restriction and innovation (Thieme, 2017). Thieme continues that the global luxury goods market is to be seen as stable and an average growth of three to four percent can be assumed (Thieme, 2017). In comparison, the German manufacturer NOMUS is in third place in Germany behind $>$ Lange \& Söhne $<$ and $>$ Glashütte Original $<$. NOMUS is a ranking of the King Index of 152.2 points on place 4661 in the DDW ranking of ${ }^{2}$ the most important medium-sized companies in Germany ('Glashütte : Kennzahlen und Rank im Mittelstandsranking', 2018).... ).

Dresden news report in January 2017 "NOMUS Glashütte put dream record" (editorial network, 2017). The newspaper continues: "The crisis in the watch industry has left the NOMUS factory in Glashütte a long way behind. 2016 was the year with the strongest sales and the most profitable year in the company's history" (Redaktionsnetzwerk, 2017). Many international magazines describe the friendly and functional appearance of the NOMUS brand (analysis of current research results and publications). The New York Times describes NOMUS in November 2017 as "emphasizing style and functionality" (Ewing, 2017). NOMUS seems to be doing everything right, the global business is very good, and the brand has established itself internationally as a sympathetic one. Thieme leads to the importance of luxury and its audience that experience, personality and responsible consumption are becoming increasingly important (Thieme, 2017). Responsible enjoyment and sustainability are becoming increasingly important for Thieme and ultimately lead to a change in the values of a brand. In an interview with the weekly newspaper die Zeit, the managing director of NOMUS Judith Borowski (Baurmann, 2018) also confirmed this. Judith Borowski describes that international customers ask her by e-mail: "There is a danger that you are dealing with people who show the Hitler salute in their spare time? (Baurmann, 2018).

Dresden, 20 October 2014: In Dresden, people are demonstrating against the increasing influx of foreigners against the Islamisation of the West. Enter the name PEGIDA ${ }^{3}$. PEGIDA will demonstrate every Monday in the coming weeks. The demonstrations are of great media interest and call on all politicians in Germany to take action. Germany is rubbing its head against the news for weeks on end. In 2015, Dresden Marketing $\mathrm{GmbH}$ commissioned a study to determine how Brandmeyer brand consulting "is perceived as the markets of Dresden, what attractive cities / locations are and what the driver > the Dresden brand < are" (Brandmeyer, 2016).

The results of the quantitative investigations can be used alternatively for this paper, since Dresden as a city is only $30 \mathrm{~km}$ away from the glassworks (Chemnitz is $70 \mathrm{~km}$ away) and the perception of potential buyers of a brand and the identification with the products projected onto the region in the. For international customers Glashütte is Saxony. Chemnitz Saxony and Dresden Saxony. From 1 May to 28 August, the study surveyed 3531 people from Germany and abroad. Among them were international tourists, researchers, academics and students. The results were compared with an earlier study from 2010 to provide information on development trends. The perception of respondents in the Saxony region is almost complete from 2010 to 2015, but remained only in Saxony, there was a decisive difference. The question was, "Is there a PEGIDA effect?" (Brandmeyer, 2016). As a result of the survey, 23\% of foreign tourists say that the PEGIDA demonstrations in Dresden (Saxony region) have a negative impact on public perception. But also 32\% of foreign tourists say that they have never heard of the PEGIDA demonstrations. Only $19 \%$ of foreign tourists say that their opinion about Dresden had a negative influence on the PEGIDA demonstrations. In other matters, only $7 \%$ of foreign tourists who declare Dresden (and thus the Saxony region) a cosmopolitan city consider.

\footnotetext{
${ }^{1}$ The Treuhandanstalt was a public-law institution in Germany with the task of privatising the state-owned enterprises of the GDR in accordance with the principles of the social market economy, was founded in the late phase of the GDR and the 'efficiency and competitiveness' of the 'Zur Sicherung' enterprise ( $\$ 8$ Treuhandgesetz) or, if this was not possible, closed down.

${ }^{2}$ DDW-Ranking: The German Economy, Portal for Change and Value Creation, Source: https://die-deutsche-wirtschaft.de/kategorie/rankings/.

${ }^{3}$ PEGIDA, Patriotic Europeans against the Islamization of the West.
} 


\section{Conclusions, discussions and recommendations}

On the basis of the available scientific studies and this statistical survey, no general statements can initially be made about a significant deterioration in the perception of the Saxony region following extremist demonstrations. The results of the survey on Dresden have remained the same, sales figures for NOMUS even increased in the reporting period, so that no significant correlation can be established for the time being. Statistically, however, the causes cannot be clearly assigned, they could also lie in the promptly initiated countermeasures in NOMUS' international marketing. Other reasons could be the zero interest rate policy taking place at the same time and the associated flight of capital into safe investments.

Since the incidents, however, NOMUS has been campaigning preventively against right-wing extremism in an internationally recognised campaign. The business leaders present themselves at every opportunity against right-wing extremist currents. Baurman writes: "In the summer of 2015, NOMUS hung a banner on the façade of its headquarters, saying: "We think internationally"". (Baurmann, 2018). With these and other messages, the management of NOMUS is clearly fighting xenophobia. NOMUS even enables its employees to attend schools against racism. With these and other measures, NOMUS has succeeded in expanding the international brand image of a cosmopolitan watch manufacturer and uncoupling negative regional influences from rightwing extremist trends and xenophobia. The rising sales figures confirm the measures taken by NOMUS in international business.

How important it is for companies to understand the relationship between people and products was investigated by Forster in 2007 (Foster, 2007). He points out that public relations work also has a high relevance in the value-added chain of companies and follows the remarks of Bruno Latour from 2005 (Latour, 1987; Mitcham, 2006). Callon and its co-authors use the term "economy of qualities" (Callon, Méadel, \& Rabeharisoa, 2002) to express the relationship between companies and consumers (Huang \& Huddleston, 2009). The consideration of the mechanisms of marketing, good or bad reputation and their effects on the business do not only take place in the end customer business, but can also be transferred to the company to company business. Companies also want to and must pay attention to their obligations to each other in terms of sustainability, can be measured against this and select their business partners according to how they behave in the field of ecology and human dignity. Persson has investigated this in his 2010 article on explorative studies of the elements of the B2B brand image and their relationship to premium prices (Persson, 2010). What efforts need to be made to address customer problems related to racism and how difficult this can be in practice to shape the moral development of employees accordingly was widely described by Thompson and Neville in 1999 (Thompson \& Neville, 1999). Thompson and Neville state, "The task of understanding standing racism in all its vicissitudes is only one step towards effective practice. Translating this understanding into professional practice and with other relevant variables is a challenge that ultimately goes hand in hand with conscious conception and practice. " (Thompson \& Neville, 1999).

What remains remarkable, however, is the connection between locally limited publicity events on the global sales markets of a manufacturer in the end customer business of the premium segment. The unique selling propositions of high-priced premium brands lead to indirect dependencies and widely networked dependencies of opinion formers which must be researched in further research. Mathews-Lefebvre suggests that another research opportunity could be to test existing brand building and proposes a model of brand building in retail as a value-added process (Mathews-Lefebvre \& Dubois, 2011).

\section{References}

1. Balbontìn, R. (2017). conceptos. TR Tiempo de Relojes, (November), 57.

2. Bassi, A. (2018). Design in Movimento. Revolution Italia, (June), 210-211.

3. Baurmann, J.G. (2018). Counterclockwise. Time, 1(September), 25.

4. Berndt, R., Altobelli, C. F., \& Sander, M. (2018). International communication management. In International Marketing Management (pp. 365-426). https://doi.org/10.1007/978-3-662-46787-9

5. Bradley, J., Morgenroth, E., \& Untiedt, G. (2011). Analysis of the macroeconomic impact of the CSF on the economy of East Germany : research project supported under EU contract Development of a model for assessing the macroeconomic impacts of structural funds in East Germany. EconPapers, 2-3. Retrieved from https://econpapers.repec.org/RePEc:ces:ifodrs:30

6. Brandmeyer, M. (2016). Success pattern of the Dresden brand. Retrieved from 
SocioEconomic Challenges, Volume 3, Issue 2, 2019

ISSN (print) - 2520-6621, ISSN (online) - 2520-6214

https://mediaserver.dresden.de/categories.php?cat_id=631

7. Buck, C. L. (2018). Life in the fast lane. ELife, 7(June), 40. https://doi.org/10.7554/eLife.35029

8. Callon, M., Méadel, C., \& Rabeharisoa, V. (2002). The economy of qualities. Economy and Society, 31, 194-217. https://doi.org/10.1080/03085140220123126

9. Develi, M. (2017). Internationales Marketing. In Marketingmanagement. https://doi.org/10.1007/978-3658-13656-7_20

10. Ewing, J. (2017). 'Our watches don't beep'. The New York Times, p. 2.

11. Foster, R. J. (2007). The work of the new economy: Consumers, Brands, and Value Creation. CULTURAL ANTHROPOLOGY, 22(4), 707-731. https://doi.org/10.1525/can.2007.22.4.707.CULTURAL

12. Franke, J.-D. (2015). So far best times for watch manufacturer Nomos. Free Press, (December), 1.

13. Glashütte : Key figures and ranking in the SME ranking. (2018). In The German Economy.

14. Hallmann, G. (2017). From Glashütte via Berlin to New YorkFrom the Ore Mountains to the whole world " More Marathon than Muckibude "' More Marathon than Muckibude "" More Marathon than Muckibude "" More Marathon than Muckibude "' More Marathon than Muckibude ". Berliner Morgenpost, pp. 1-10.

15. Huang, Y., \& Huddleston, P. (2009). Retailer premium own-brands : Retailer creating customer loyalty through own-brand products advantage. International Journal of Retail \& Distribution Management, 37(11), 975-992. https://doi.org/10.1108/09590550910999389

16. Janning backfish, N. (2018). Deterministic environmental factors for competence and qualification requirements of logistics companies. In Competence and Qualification Requirements in Logistics (pp. 139-273). Springer Nature.

17. Smart guy, J. (2011). Growth and employment in Dresden - Why is Dresden growing more slowly than the rest of Saxony? Publications by Researchers Of The Ifo Institute - Leibniz Institute For Economic Research At The University Of Munich Ifo Dresden Reports, Ifo Institute - Leibniz Institute For Economic Research At The University Of Munich, 10th Retrieved from http://hdl.handle.net/10419/169968

18. King, V. (2017a). Communication. In Basics of luxury and premium brand management (pp. 79-95). https://doi.org/10.1007/978-3-658-10746-8

19. King, V. (2017b). Distribution and sales promotion. In Fundamentals of Luxury and Premium Brand Management (pp. 67-78). https://doi.org/10.1007/978-3-658-10746-8

20. Latour, B. (1987). Reassembling the Social (p. 311). p. 311. Oxford.

21. Märk, S., \& Situm, M. (2018). A business opportunity - an entrepreneur - a country and then the world. In family businesses and their stakeholders (pp. 207-235). Springer Trade Media Wiesbaden.

22. Mathews-Lefebvre, C., \& Dubois, P.-L. (2011). Case study Retail branding as a value creation process : managerial and research priorities. Thought Leaders International Conference in Brand Management Conference, 30. Lugano.

23. Mitcham, C. (2006). Book Reviews. Science Studies, 19, 93-95.

24. Persson, N. (2010). Industrial Marketing Management An exploratory investigation of the elements of B2B brand image and its relationship to price premium. Industrial Marketuing Management, 39, 12691277. https://doi.org/10.1016/j.indmarman.2010.02.024

25. Editorial network. (2017). Nomos Glashütte presents a dream balance. Dresden Latest News.

26. Reich, M. (1981). The Economics of Racism. In A Political-Economic Analysis (pp. 1-6).

27. Shteyngart, G. (2017). Time Out. Black Enterprise, 37(March), 74. Retrieved from http://search.ebscohost.com/login.aspx ?direct=true \&db=bth\&AN=22902844\&site=ehost-live

28. Thieme, M. W. P. D. (2017). Further development of the luxury brand in digital times. Brand, e-journal, (April), 72-78. https://doi.org/10.1007/978-3-658-11090-1

29. Thompson, C. E., \& Neville, H. A. (1999). Racism, Mental Health, and Mental Health Practice. The Counseling Psychologist, 27, 155-223. https://doi.org/10.1177/0011000099272001

30. Will, R. (2018). Clear message. The mirror, 2(September), 70-71. 